\title{
ANALISIS PENGARUH KEBIJAKAN DIVIDEN (DIVIDEND PAYOUT RATIO DAN DIVIDEND YIELD) TERHADAP VOLATILITAS HARGA SAHAM (Studi Empiris pada Perusahaan Kelompok LQ45 yang terdaftar di BEI)
}

\author{
Andri Novius \\ Fakultas Ekonomi dan Sosial UIN Sultan Syarif Kasim Riau - Pekanbaru \\ E-mail: andrinovius@uin-suska.ac.id
}

\begin{abstract}
Abstrak
Penelitian ini bertujuan untuk mengetahui bagaimana pengaruh kebijakan dividen (dividend payout ratio dan dividend yield) terhadap volatilitas harga saham pada perusahaan kelompok LQ45 yang terdaftar di BEI periode 20112014.

Penelitian ini menggunakan data sekunder dari perusahaan kelompok LQ45 yang terdaftar Di Bursa Efek Indonesia dengan populasi 45 perusahaan. Metode pemilihan sampel adalah purposive sampling, sehingga di peroleh sampel sebanyak 10 perusahaan kelompok LQ45 yang terdaftar di Bursa Efek Indonesia tahun 2011-2014. Analisis data menggunakan alat analisis uji regresi linier berganda dan uji asumsi klasik yang terdiri dari uji normalitas, uji multikolinearitas, uji heteroskedastisitas, dan uji autokorelasi. Pengujian hipotesis dilakukan dengan pengujian $t$, uji f, dan determinasi $\left(R^{2}\right)$.

Hasil analisis data atau regresi linier berganda menunjukkan bahwa secara simultan dividend payout ratio dan devidend yield berpengaruh signifikan terhadap volatilitas harga saham. Variabel independen dapat menjelaskan pengaruh volatilitas harga saham sebesar 20,7\% sedangkan sisanya sebesar 79,3\% dipengaruhi oleh faktor lain yang tidak dimasukkan dalam model regresi ini. Secara parsial dividend payout ratio tidak memiliki pengaruh signifikan terhadap volatilitas harga saham. Sedangkan dividend yield memiliki pengaruh signifikan terhadap volatilitas harga saham.
\end{abstract}

Kata Kunci : Volatilitas Harga Saham, Dividend Payout Ratio, dan Dividend Yield.

\section{PENDAHULUAN}

Dalam konteks investasi saham, harapan keuntungan di masa mendatang disebut return (Tandelilin, 2001). Menurut Jones (2000) return dapat berupa yield (dividend) dan capital gain (loss). Yield adalah cash flow yang dibayarkan secara periodik kepada pemegang saham (dalam bentuk deviden), sedangkan capital gain (loss) adalah selisih antara harga saham pada saat pembelian dengan harga saham pada saat penjualan. Baik investor pengharap imbalan yield (dividen) maupun capital gain, keduanya sama-sama membutuhkan informasi mengenai dividen. Bagi para investor pengharap imbalan dividen, informasi tentang kebijakan dividen penting karena kebijakan dividen adalah salah satu faktor-faktor penentu keputusan apakah mereka 
akan menginvestasikan dana mereka atau tidak. Informasi tentang naikturunnya dividen tunai yang dibagikan perusahaan merupakan salah satu informasi yang dipandang cukup penting, karena dalam informasi tersebut Sedangkan bagi investor pengharap imbalan capital gain, jika disimpulkan berdasarkan teori Efficiency Market Hyphotesis, informasi tentang kebijakan dividen penting bagi mereka karena harga saham bereaksi terhadap informasi yang ada di pasar, salah satunya adalah informasi tentang pembagian dividen. Informasi tentang pembagian dividen dipercaya akan dapat mempengaruhi perilaku harga saham di bursa akibat dari aksi investor yang menginginkan keuntungan dari kejadian (moment) tersebut (Kaweny, 2007).

Krisis yang terjadi terkait harga saham menyebabkan fluktuasi harga saham di Bursa Efek Indonesia meningkat. Hal ini menambah tingkat resiko dalam investasi di pasar modal. Tidak terkecuali perusahaan tergolong indeks LQ45 yang merupakan perusahaan teraktif dan memiliki likuiditas yang tinggi. Dalam penelitian ini peneliti memfokuskan terhadap perusahaan yang masuk dalam kelompok LQ45 dari tahun 2011-2014. LQ45 merupakan suatu kumpulan yang didalamnya terdapat perusahaan yang sahamnya memiliki tingkat likuiditas dan kapasitas pasar yang tinggi. LQ45 mendeskripsikan bahwa saham perusahaan tersebut telah memenuhi kriteria tertentu yang ditetapkan oleh Bursa Efek. Indeks LQ45 sebagai salah satu indikator indeks saham di BEI yang dapat mengandung muatan informasi (information content) yang berkenaan dengan prospek keuntungan yang akan diperoleh suatu perusahaan di masa yang akan datang (Prasetiono, 2000).

dijadikan acuan sebagi bahan untuk menilai kinerja perdagangan saham. Diantara saham-saham yang ada di pasar modal Indonesia, saham LQ45 yang ada di Bursa Efek Indonesia merupakan banyak diminati oleh investor.

Informasi yang terdapat dalam kebijakan dividen (tentang besarnya dividen kas yang dibagikan perusahaan) merupakan salah satu informasi yang dipandang cukup penting bagi para investor, karena dalam informasi tersebut mengandung muatan informasi (information content) yang berkenaan dengan prospek keuntungan yang akan diperoleh suatu perusahaan di masa yang akan datang. Sementara penelitian mengenai pengaruh perubahan jumlah dividen kas terhadap harga saham masih memberikan hasil yang berlainan. Ada penelitian yang menyatakan bahwa perubahan pembayaran dividen mempunyai kandungan informasi sehingga mempengaruhi harga saham, tetapi ada juga penelitian yang menyatakan sebaliknya yaitu perubahan pembayaran dividen tidak mempunyai kandungan informasi.

Kebijakan dividen diukur dengan menggunakan dua ukuran, yaitu dividend yield dan dividend payout ratio, karena dua ukuran tersebut memiliki makna yang berbeda. Dividend yield 
menggambarkan seberapa besar income return yang akan didapatkan investor atas sejumlah uang yang mereka investasikan. Sedangkan dividend payout ratio menggambarkan seberapa besar laba bersih perusahaan yang digunakan untuk membayar dividen ke investor.

Tujuan dari penelitian ini adalah untuk menganalisis pengaruh dividend payout ratio (DPR) terhadap volatilitas harga saham

\section{TINJAUAN PUSTAKA}

\section{Signalling Hypothesis (Dividend Signalling Theory)}

Ross (1977) menyatakan, agar suatu signal/isyarat (informasi) bermanfaat harus memenuhi empat hal. Pertama, manajemen harus selalu mempunyai dorongan yang tepat untuk mengirimkan isyarat yang jujur, walaupun beritanya buruk. Kedua, isyarat dari suatu perusahaan yang sukses tidak mudah diterima oleh pesaingnya yang kurang sukses. Ketiga, isyarat itu harus mempunyai hubungan yang cukup berarti dengan kejadian yang dapat diamati (misalnya dividen yang lebih tinggi saat ini akan dihubungkan dengan arus kas yang tinggi di masa yang akan datang). Keempat, tidak ada cara menekan biaya yang lebih efektif dari pada pengiriman isyarat yang sama.

\section{Efficiency Market Hypothesis} (EMH)

Sebuah teori investasi yang menyatakan bahwa dalam pasar efisien, harga saham akan selalu berkorelasi atau mencerminkan pada perusahaan kelompok LQ45 yang terdaftar di Bursa Efek Indonesia, menganalisis pengaruh dividend yield terhadap volatilitas harga saham pada perusahaan kelompok LQ45 yang terdaftar di Bursa Efek Indonesia, dan menganalisis pengaruh dividend payout ratio dan dividend yield terhadap volatilitas harga saham pada perusahaan kelompok LQ45 yang terdaftar di Bursa Efek Indonesia

semua informasi yang ada di pasar. Hendriksen dan Breda (2000) lebih lanjut menjelaskan bahwa teori ini hanya berlaku jika :

a. Semua informasi yang tidak relevan tidak dihiraukan investor

b. Tidak ada biaya transaksi untuk memperdagangkan saham

c. Semua informasi yang ada bersifat equal (imbang, sama rata) untuk semua investor

d. Semua investor memiliki ekspetasi yang bersifat homogen (homogenous expectations).

Dalam kata lain, teori EMH mengatakan bahwa kapanpun informasi baru yang relevan terkait dengan saham muncul, hal itu akan mengubah ekspektasi dari para investor, dan mengakibatkan dengan adanya perubahan harga equilibrium dari saham tersebut secara cepat dan tepat.

\section{Saham}

Saham adalah sebuah surat berharga yang dikeluarkan oleh sebuah perusahaan yang 
berbentuk perseroan terbatas (emiten) yang menyatakan bahwa pemilik saham tersebut adalah juga pemilik sebagian dari perusahaan itu. Husnan (2001) menyebutkan bahwa sekuritas (saham) merupakan secarik kertas yang menunjukkan hak pemodal (yaitu pihak yang memiliki kertas tersebut) untuk memperoleh bagian dari prospek atau kekayaan organisasi yang menerbitkan sekuritas tersebut dan berbagai kondisi yang memungkinkan pemodal tersebut menjalankan haknya.

\section{Tinjauan Saham dalam Islam}

Dalam ajaran Islam, bahwa kegiatan berinvestasi dapat dikategorikan sebagai kegiatan ekonomi yang sekaligus kegiatan tersebut termasuk kegiatan muamalah yaitu suatu kegiatan yang mengatur hubungan antar manusia. Sementara itu berdasarkan kaidah Fikih, bahwa hukum asal dari kegiatan muamalah itu adalah mubah (boleh) yaitu semua kegiatan dalam pola hubungan antar manusia adalah mubah (boleh) kecuali yang jelas ada larangannya (haram). Ini berarti ketika suatu kegiatan muamalah yang kegiatan tersebut baru muncul dan belum dikenal sebelumnya dalam ajaran Islam maka kegiatan tersebut dianggap dapat diterima kecuali terdapat implikasi dari Al Qur'an dan Hadist yang melarangnya secara implisit maupun eksplisit.

\section{Untuk}

mengimplementasikan seruan investasi tersebut, maka harus diciptakan suatu sarana untuk berinvestasi. Banyak pilihan orang untuk menanamkan modalnya dalam bentuk investasi. Salah satu bentuk investasi adalah menanamkan hartanya dipasar modal.

Pasar modal bertindak sebagai penghubung antara para investor dengan perusahaan ataupun institusi pemerintah melalui perdagangan instrumen keuangan jangka panjang. Sayangnya selama ini pasar modal menjadi wadah ekonomi yang paling banyak menjalankan transaksi yang dilarang seperti bunga (riba), perjudian (gambling/maysir), gharar, penipuan dan lain-lain. Upaya untuk melakukan islamisasi pada sektor perputaran modal yang sangat vital bagi perekonomian modern ini semakin gencar. Dalam rangka mengkaji reksadana berdasarkan syariah, peserta lokakarya Alim-Ulama MUI menetapkan sejumlah dalil sebagai alasan, yaitu dalil yang diambil dari ayat Al-Qur'an, hadist dan pendapat ulama.

Jual beli saham dalam Islam pada dasarnya adalah merupakan bentuk Syirkah mudhorabah, diantara para pengusaha dan pemilik modal sama-sama berusaha yang nantinya hasilnya bisa dibagi bersama. Mudharabah, merupakan teknik pendanaan dimana pemilik modal menyediakan dana untuk digunakan oleh unit defisit dalam kegiatan produktif dengan dasar loss and profit shearing.

Dalil naqli tentang saham (mudharabah), Firman Allah 
SWT dalam (Q.S. Al-Muzammil: 20)

Artinya:

"Sesungguhnya tuhanmu mengetahui bahwasnya kamu berdiri (sembahyang) kurang dari dua pertiga malam, atau seperdua malam atau sepertiga nya dan (demikian pula) segolongan dari orang-orang yang bersama kamu. Dan Allah mengetahui bahwakamu sesekali tidak dapat menentukan batasbatas waktu-waktu itu, maka dia memberi keringanan kepadamu, karena itu bacalah apa yang mudah bagimu dari Al-Qur'an. Dia mengetahui bahwa akan ada diantara kamu orang-orang yang sakit dan orang-orang yang berjalan dimuka bumi mencari sebagian karunia Allah swt. Dan orang-orang yang lain lagi

\section{Gambar 1}

Desain Penelitian

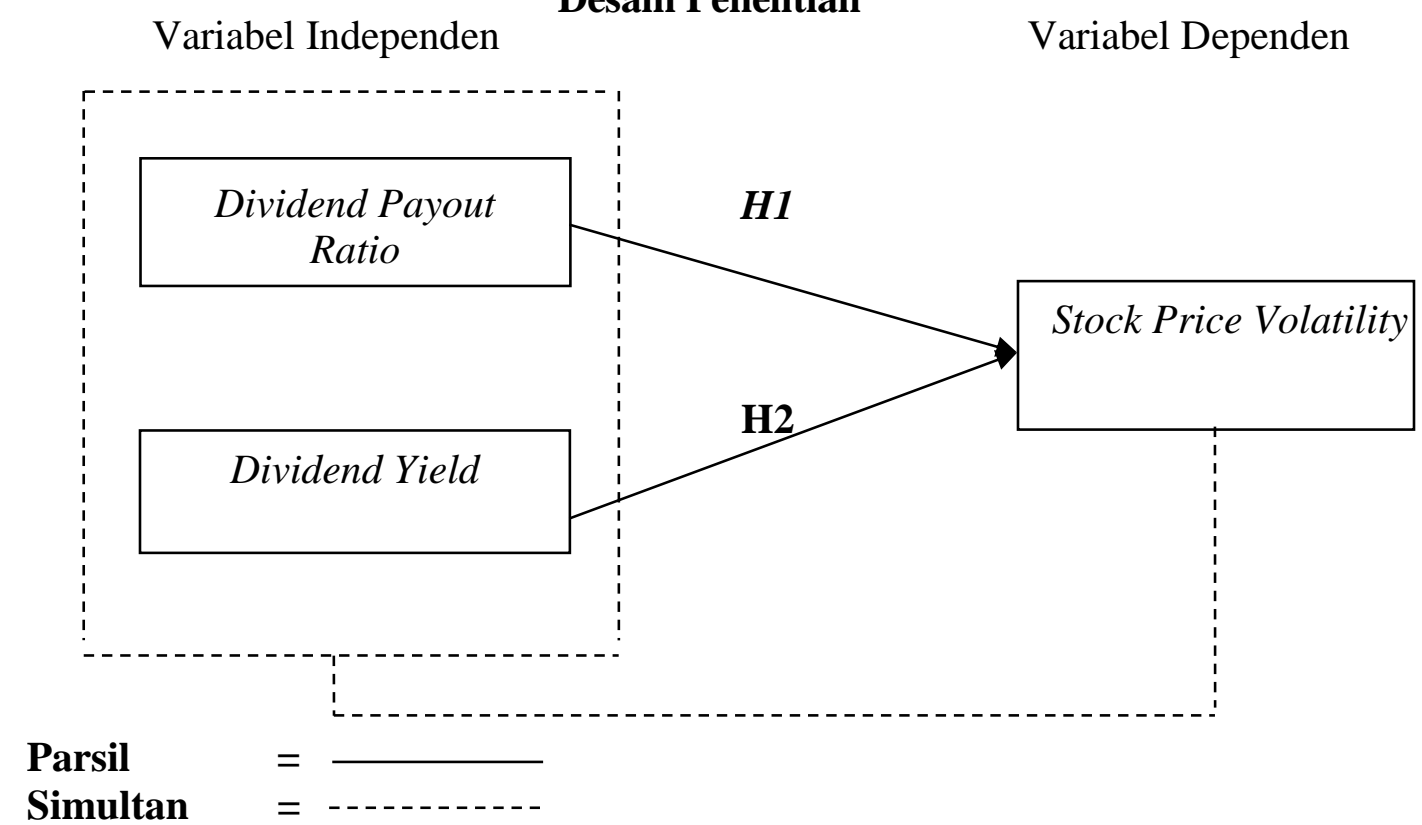

berperang dijalan Allah, maka bacalah apa yang mudah (bagimu) dari Al-Qur'an dan dirikanlah sembahyang, tunaikanlah zakat dan berikanlah pinjaman yang baik dan kebaikan apa saja yang kamu perbuat untuk dirimu niscaya kamu memperoleh (balasan) nya disisi Allah sebagai balasan yang paling baik dan yang paling besar pahalanya dan memohonlah ampunan kepada Allah, sesungguhnya Allah maha pengampun lagi maha penyayang." (Q.S.

Al.Muzammil: 20)

Berdasarkan latar belakang dan penjelasan mengenai teori dan didasarkan penelitian terdahulu, maka desain penelitian ini dapat digambarkan sebagai berikut:
Simultan 
Dari uraian dan penjelasan masalah yang dikemukakan di atas maka dapat diambil kesimpulan berupa hipotesis, yaitu:

H1 : Diduga Dividend Payout Ratio berpengaruh negatif terhadap volatilitas harga saham pada perusahaan kelompok LQ45 yang terdaftar di Bursa Efek Indonesia.

$\mathrm{H} 2$ : Diduga Dividend Yield berpengaruh negatif terhadap Volatilitas Harga Saham pada perusahaan kelompok LQ45 yang terdaftar di Bursa Efek Indonesia.

H3 : Diduga Dividend Payout Ratio dan Dividend Yield berpengaruh terhadap Volatilitas Harga Saham pada perusahaan kelompok LQ45 yang terdaftar di Bursa Efek Indonesia.

METODE PENELITIAN

Variabel dan Defenisi Operasional

Variabel

\section{Tabel 1}

Definisi Operasional Variabel

\begin{tabular}{|c|c|c|c|}
\hline No & Variabel & Pengukuran & Sumber Data \\
\hline $\mathbf{1}$ & $\begin{array}{c}\text { Price vol } \\
\text { Y }\end{array}$ & PriceVol $=\sqrt[2]{\frac{\sum_{i}^{n}=1\left\{(H i-L i) /\left(\frac{H i+L i}{2}\right)\right\}}{n}}$ & $\begin{array}{c}\text { Perhitungan dari } \\
\text { catatan harga saham } \\
\text { penutupan harian } \\
\text { (daily closing price })\end{array}$ \\
\hline $\mathbf{2}$ & $\begin{array}{c}\text { Dividend } \\
\text { Payout Ratio } \\
\mathrm{X} 1\end{array}$ & Payout $=\frac{\text { Deviden per share }(D P S)}{\text { Earning pe share }(E P S)}$ & $\begin{array}{c}\text { Perhitungan dari } \\
\text { laporan keuangan }\end{array}$ \\
\hline $\mathbf{3}$ & $\begin{array}{c}\text { Dividend } \\
\text { Yield } \\
\mathrm{X} 2\end{array}$ & Yield $=\frac{\text { Deviden per share }(D P S)}{\text { Share Price }}$ & $\begin{array}{c}\text { Perhitungan dari } \\
\text { laporan keuangan }\end{array}$ \\
\hline
\end{tabular}

Populasi dalam penelitian ini adalah seluruh perusahaan yang termasuk dalam LQ 45 dari tahun
2011-2014 di Bursa Efek Indonesia (BEI). 
Tabel 2

Seleksi sampel

\begin{tabular}{|l|l|c|}
\hline \multicolumn{1}{|c|}{ Keterangan } & Jumlah Perusahaan \\
\hline 1 & $\begin{array}{l}\text { perusahaan yang listing dalam indeks LQ45 di BEI } \\
\text { periode 2011-2014 }\end{array}$ & 45 \\
\hline 2 & $\begin{array}{l}\text { Perusahaan mempublikasikan laporan keuangan } \\
\text { tahunan lengkap untuk periode 31 Desember } \\
2011-31 \text { Desember 2014 }\end{array}$ & 19 \\
\hline 3 & $\begin{array}{l}\text { Perusahaan yang selalu membagikan dividen } \\
\text { selama tiga tahun berturut-turut dari tahun 2011- } \\
\text { 2014 saham }\end{array}$ & 10 \\
\hline 4 & $\begin{array}{l}\text { Perusahaan memiliki catatan harga san } \\
\text { penutupan harian (daily closing price) dari saham } \\
\text { biasa dari tahun 2011-2014 }\end{array}$ & 10 \\
\hline Jumlah perusahaan yang menjadi sampel & \\
\hline
\end{tabular}

Sumber : Data diolah 2017

Tabel 3

Daftar Perusahaan yang Menjadi Sampel

\begin{tabular}{|c|c|c|}
\hline NO & KODE & NAMA PERUSAHAAN \\
\hline 1 & AALI & Astra Agro Lestari Tbk. \\
\hline 2 & BBNI & Bank Negara Indonesia (Persero) Tbk. \\
\hline 3 & BBRI & Bank Rakyat Indonesia Tbk. \\
\hline 4 & BDMN & Bank Danamon Tbk \\
\hline 5 & BMRI & Bank Mandiri (Persero) Tbk. \\
\hline 6 & KLBF & Kalbe Farma Tbk. \\
\hline 7 & LSIP & PP London Sumatra Indonesia Tbk. \\
\hline 8 & PTBA & Bukit Asam (Persero) Tbk \\
\hline 9 & SMGR & Semen Gresik (Persero) Tbk \\
\hline 10 & UNTR & United Tractor Tbk \\
\hline
\end{tabular}

Jenis data yang dipakai dalam penelitian ini merupakan data sekunder yang bersumber dari dokumentasi perusahaan. Data sekunder merupakan data yang diperoleh dari sumber yang sudah ada dan tidak perlu dicari sendiri oleh peneliti (Sekaran, 2007).

Data yang digunakan dalam penelitian ini adalah laporan 
keuangan tahunan dari perusahaan yang terdaftar pada indeks LQ 45 di Bursa Efek Indonesia dari tahun 2011 sampai tahun 2014 dan membagi selalu dividen dari tahun 2011 sampai tahun 2014.

$$
\text { Metode analisis yang }
$$

digunakan untuk menguji hipotesis dalam penelitian ini adalah regresi berganda (multiple regression analysis). Untuk menjamin keakuratan data, maka sebelum dilakukan analisis regresi untuk menguji hipotesis dalam penelitian ini, dilakukan terlebih dahulu analisis statistik deskriptif. Selain itu, dilakukan pengujian kelayakan model regresi untuk menilai model regresi.

\section{HASIL DAN PEMBAHASAN Analisis Data}

Sebelum dilakukan uji hipotesis, terlebih dahulu dilakukan pengujian kualitas data dan Uji Asumsi Klasik tehadap data yang di dapat. Berdasarkan pengujian, telah didapatkan data yang berkualitas dan dapat dilanjutkan dengan pengujian hipotesis.

\section{Analisis Regresi Linier Berganda \\ Persamaan regresi dapat dilihat dari tabel hasil uji coefficients berdasarkan ouput SPSS versi 21 terhadap ke 2 variabel independen yaitu DPR dan DY terhadap Volatilitas Harga saham ditunjukkan pada tabel berikut ini :}

\section{Tabel 4}

Hasil Perhitungan Regresi

\begin{tabular}{|c|c|c|c|c|}
\hline \multicolumn{5}{|c|}{ Coefficients $^{a}$} \\
\hline \multirow{2}{*}{\multicolumn{2}{|c|}{ Model }} & \multicolumn{2}{|c|}{ Unstandardized Coefficients } & Standardized \\
\hline & & $B$ & Std. Error & Beta \\
\hline \multirow{3}{*}{1} & (Constant) & ,157 & ,024 & \\
\hline & DPR &,- 002 &, 001 &,- 437 \\
\hline & DY & ,008 & ,003 & ,685 \\
\hline
\end{tabular}

a. Dependent Variable: PRICE_VOL

Sumber : Data Olahan SPSS

\section{Pengujian Variabel Secara Parsial (T-Test)}

Tabel 5

Hasil Uji Hipotesis Parsial Coefficients $^{a}$

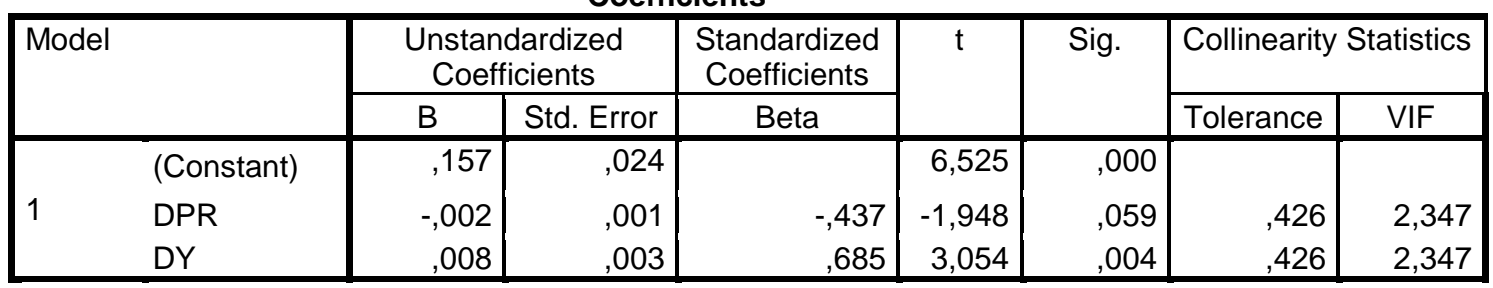

a. Dependent Variable: PRICE_VOL

Sumber : Data Olahan SPSS 


\section{Uji Hipotesis Pertama}

Hipotesis pertama yang diajukan dalam penelitian ini adalah untuk menguji bagaimana pengaruh dividend payout ratio (DPR) terhadap Volatilitas harga saham. Dari hasil SPSS pada tabel 5 diatas diketahui nilai $t_{\text {hitung }}$ sebesar $-1,948$, sedangkan $\mathrm{t}_{\text {tabel }} 2,026$, dimana $\mathrm{t}_{\text {hitung }}$ $1,948<\mathrm{t}_{\text {tabel }}-2,026$, dengan tingkat signifikan sebesar 0,059 berada lebih tinggi pada $\alpha=0,05$. Maka hipotesis pertama yang menyatakan bahwa dividend payout ratio (DPR) berpengaruh signifikan terhadap volatilitas harga saham ditolak, artinya bahwa dividend payout ratio tidak berpengaruh terhadap volatilitas harga saham.

Pengujian Variabel Secara Simultan (F-Test)

Tabel 6

Hasil Uji Hipotesis Simultan

\begin{tabular}{|rl|r|r|r|r|r|}
\hline \multicolumn{1}{|c|}{ MNOVA $^{\text {a }}$} \\
\hline \multirow{4}{*}{1} & Sum of Squares & df & Mean Square & F & Sig. \\
\cline { 3 - 7 } & Regression &, 042 & 2 &, 021 & 4,819 &, $014^{\mathrm{b}}$ \\
& Residual &, 160 & 37 &, 004 & & \\
& Total &, 201 & 39 & & & \\
\hline
\end{tabular}

a. Dependent Variable: PRICE_VOL

b. Predictors: (Constant), DY, DPR

Sumber : Data Olahan SPSS

Pengujian ini adalah untuk menguji $\mathrm{H}_{3}$ yang menyatakan bahwa dividend payout ratio, dividend yield berpengaruh terhadap volatilitas harga saham.

Berdasarkan hasil perhitungan diperoleh nilai $f$ test ( $\mathrm{f}$ hitung) sebesar 4,819 dengan tingkat signifikasi sebesar 0,014 (dibawah 0,05 ) atau $\mathrm{t}$ hitung $=4,819$ lebih besar dari $f$ tabel $=3,252$ $(=\mathrm{FINV}(0,05 ; 2 ; 37))$. Memperhatikan hasil uji test ini, maka hipotesis

\section{Uji Hipotesis Kedua}

Hipotesis kedua yang diajukan dalam penelitian ini adalah untuk menguji bagaimana pengaruh dividend yield (DY) terhadap Volatilitas harga saham. Dari hasil SPSS pada tabel 5 diatas diketahui nilai $t_{\text {hitung }}$ sebesar 3,054 , sedangkan $\mathrm{t}_{\text {tabel }} 2,026$, dimana $\mathrm{t}_{\text {hitung }} 3,054>\mathrm{t}_{\text {tabel }}$ 2,026, dengan tingkat signifikan sebesar 0,004 berada lebih rendah pada $\alpha=0,05$. Maka hipotesis kedua yang menyatakan bahwa devidend yield (DY) berpengaruh signifikan terhadap volatilitas harga saham diterima, artinya bahwa dividend yield berpengaruh terhadap volatilitas harga saham. 


\section{PENUTUP \\ Simpulan}

Kesimpulan yang dapat ditarik dari hasil analisis regresi dan pengujian hipotesis dalam penelitian ini adalah sebagai berikut :

1. Secara parsial variabel dividend payout ratio (DPR) memiliki tingkat signifikan diatas 0,05 yaitu sebesar 0,059, dan tidak berhasil menunjukkan adanya pengaruh yang signifikan terhadap volatilitas harga saham. Hal ini tidak mendukung $\mathrm{H} 1$ yang menyatakan bahwa dividend payout ratio berpengaruh negatif terhadap volatilitas harga saham .

2. Secara parsial variabel dividend yield (DY) memiliki tingkat signifikan dibawah 0,05 yaitu sebesar 0,004, dan berhasil menunjukkan adanya pengaruh yang signifikan terhadap volatilitas harga saham. Hal ini mendukung $\mathrm{H} 2$ yang menyatakan bahwa dividend yield berpengaruh positif terhadap volatilitas harga saham.

3. Hasil uji koefisien determinasi diperoleh nilai $\mathrm{R}$ Square 0,207 atau $20,7 \%$. Hasil ini berarti menunjukkan hanya kontribusi $20,7 \%$ dari variabel dividend payout ratio dan dividend yield terhadap volatilitas harga saham. Sedangkan sisanya $79,3 \%$ dijelaskan oleh variabel lain yang tidak diteliti dalam penelitian ini.

\section{Saran}

Saran untuk penelitian ini bagi peneliti selanjutnya:

1. Pada penelitian selanjutnya jika ingin melakukan penelitian dengan tema sejenis sebaiknya memperpanjang periode pengamatan sehingga pengaruh dapat dilihat dari jangka waktu yang lebih panjang lagi.

2. Untuk penelitian yang akan datang diharapkan juga agar dapat menguji beberapa variabel atau menambah variabel lain yang diduga memiliki pengaruh terhadap volatilitas harga saham.

\section{DAFTAR PUSTAKA}

Al- Quran Surat Al-Muzammil ayat: 20

Ghozali, Imam. 2013. Aplikasi Analisis Multivariate dengan Program IBM SPSS 21, Cetakan VII. Semarang: Badan Penerbit Universitas Diponegoro.

Hendriksen, Eldon S. dan Michael

F. van Breda. 1992. Accounting Theory (Homewood), 5th Edition. Illinois: Irwin Publishers.

Husnan,Suad. 2001. Dasar-dasar

Manajemen Keuangan.

Yogyakarta: UPP AMP YKPN.

Jensen, M. C. dan C. W. Smith. 1984. The Modern Theory of Corporate Finance. McGraw Hill.

Jones, Charles P. 2000. Investment: Analysis and Management, 7th Edition. New York: John Willey and Sons Inc.

Kaweny, Siwi Puspa. 2007. " Studi Keterkaitan Antara Dividend Payout Ratio, Financial Leverage dan Investasi dalam Pengujian Hipotesis Pecking Order ( Studi Kasus: Perusahaan Manufaktur yang Terdaftar dan Listed di Bursa Efek 
Jakarta Periode 20042005)". Program Pasca Sarjana. Universitas Diponegoro. Semarang.

Prasetiono. 2000. Pengaruh Pengumuman Dividen Terhadap Abnormal Return Saham Di Bursa Efek Jakarta. Media Ekonomi dan Bisnis, Vol. XII, No. 1, Juni.

Ross, S. A. 1977. The Determinant of Financial Structure: The Incentive Signalling Approach. Bell Journal of Economics, Vol. 8, No. 1,
23-40.

Sekaran, Uma. 2007."Research Methods For Businness". Salemba Empat. Jakarta.

Sundjaja Ridwan S. dan Inge Barlian. 2003. Manajemen Keuangan 1, Edisi kelima. Jakarta: Literata Lintas Media.

Tandelilin, Eduardus. 2001. Analisis Investasi dan Manajemen Portofolio, Edisi Pertama. Yogyakarta: BPFE UGM.

www.idx.co.id

www.sahamok.com

www.yahoofinance.com 